\title{
Mineralogy of Metacarbonate Rocks and Garnet Deposits at Two Selected Areas at Asir Region, Southwestern KSA
}

\author{
Asaad Mohammed Bakor Moufti \\ Department of Mineral Resources and Rocks, Faculty of Earth Sciences, \\ King Abdul Aziz University, Jeddah, Saudi Arabia. \\ E-mail:ambmoufti@hotmail.com \\ Received June 21, 2011; revised August 14, 2011; accepted September 27, 2011
}

\begin{abstract}
The mineralogical data materialized in the present work suggest that the previously described skarns at Ad Darb in the literature are actually marble deposits intercalated with schists and phyllites of different compositions. The marble and associated metasediments lie to the west of striking ridges of marbles that are nearly aligned in the NNW-SSE direction. Garnet at Al Madhiq occurrence often occurs in the form of bands conformable with rock foliation (gneissosity and schistosity). It is suggested that the paragenesis "quartz-garnet-epidote" is developed due to the percolation of some Al-rich solutions along rock foliation of the hornblende gneiss, i.e. metasomatic garnet. Careful field investigation collaborated with petrographic and SEM studies, suggest the occurrence of another garnetiferous paragenesis associating quartz, mica and feldspar in pegmatites, aplites and quartz veins, i.e. exclusively igneous garnet. Metasomatic garnet in the calc-silicates of Al Madhiq is of grossular composition. It is commonly unzoned but some distinctly to slightly zoned crystals are observed where the core is andradite-rich and the rim is grossular. Metasomatic events responseble for growth of garnet in the calc-silicates led also to formation of epidote post-dating grossular. Hand specimens, microscopic investigation and BSE images prove that this epidote post-dates and replaces grossular, and even rims it in some instances. Igneous garnet at Al Madhiq (almandine-spessartine) is found only in pegmatites and aplites that are genetically related to alkali granitoids. Sulphides (dominated by pyrite) occur in intemate association with domains rich in grossular and hence these sulphides are more likely hydrothermal indicating reducing conditions for formation of grossular.
\end{abstract}

Keywords: Asir, Metacarbonate, Calc-Silicates, Grossular, Almandine-Spessartine, Metasomatic, Igneous.

\section{Introduction}

The present paper documents the main geological and mineralogical aspects of some meta-carbonate rocks from Asir terrane, particularly from Ad Darb and Al Madhiq areas. Here, the present investigators aim to define any possible skarns and calc-silicates accurately, particularly those containing garnet in economic quantities.Marble and skarn deposits were documented previously in Saudi Arabia by some authors, e.g. [1-3].

According to the geological map of Fairer [4] shown in Figure 1, there is a considerable mass of skarn deposit cropping close to the town of Ad Darb in Asir terrain, near the Red Sea coast. Careful survey by the present investigators revealed that nothing documents such nomenclature in literature and now detailed petrologic studies have been carried out in order to decide whether they are actually skarns or not. The nomenclature given by Fairer [4] did not rely on sampling and petrographic rock identification. It was possibly suggested because of stereoscopic investigation using topographic sheets and aerial photographs.

The paper aims to characterize and distinguish metacarbonate rocks at both Ad Darb and Al Madhiq areas at Asir terrain in order to fit their proper lithostratigraphic position, in addition to synopsis on their mineralogical composition and possible economic potentialities. In this respect, it is proposed to distinguish metacarbonate rocks (either in the field or microscopically). Also, the paper furnishes a trial to testify the presence of possible skarn deposita at Al Madhiq area which were previously suggested by some authors [5-7]. 


\section{Procedures and Techniques}

For the sake of a detailed petrographic study, several representative samples were collected from the two studied areas at the Asir terrain, namely Ad Darb and AlMadhiq. Thin- and polished-sections of representative samples were selected for the petrographic study, both in transmitted and reflected lights.

X-ray diffractograms were obtained using a PW 1840 Philips diffractometer with Ni-filtered $\mathrm{Cu} \mathrm{K} \alpha$ radiation at $30 \mathrm{Kv}$ and $20 \mathrm{~mA}$ and normal scanning rate of $12 \theta / 1$ $\mathrm{cm} /$ minute, housed at the research laboratories of Faculty of Earth Sciences, King Abdulaziz University. For additional credibility, some representative ground samples were also prepared and sent to the XRD laboratory of the Saudi Geological Survey (SGS) in Jeddah in order to verify the mineralogical identification of ore minerals and accessory silicate minerals of low modal abundance. For the identification of both silicate and ore minerals in the investigated samples, selected Powder Diffraction Data for minerals documented in the ASTM electronic cards were used.

Scanning electron microscopy with energy dispersive
X-ray attachment (SEM-EDX) will be conducted on a Philips machine Model XL 30 workable at $30 \mathrm{kV}$ accelerating voltage housed at the Central Laboratories of the Geological Survey of Egypt. The obtained data are in the form of spot semi-quantitative microanalyses of some ore minerals, calc-silicate minerals (e.g. garnet, feldspars, epidote, zircon, amphibole \& sulphides) and finally some accessories such as apatite and zircon. Such SEM survey can help to detect any metallic mineralization in the studied skarn, and accordingly can be considered here as a powerful tool for metal exploration.

\section{Geologic Set Up and Field Observations}

\subsection{Ad Darb Marble Deposits}

Current field observations by the present author proved that there are no skarns there at all, and the whole mass is actually marble deposits intercalated with schists and phyllites of variable compositions. The marble and associated metasediments lie to the west of striking ridges of marbles that nearly aligned in the NNW-SSE direction (Figure 1).

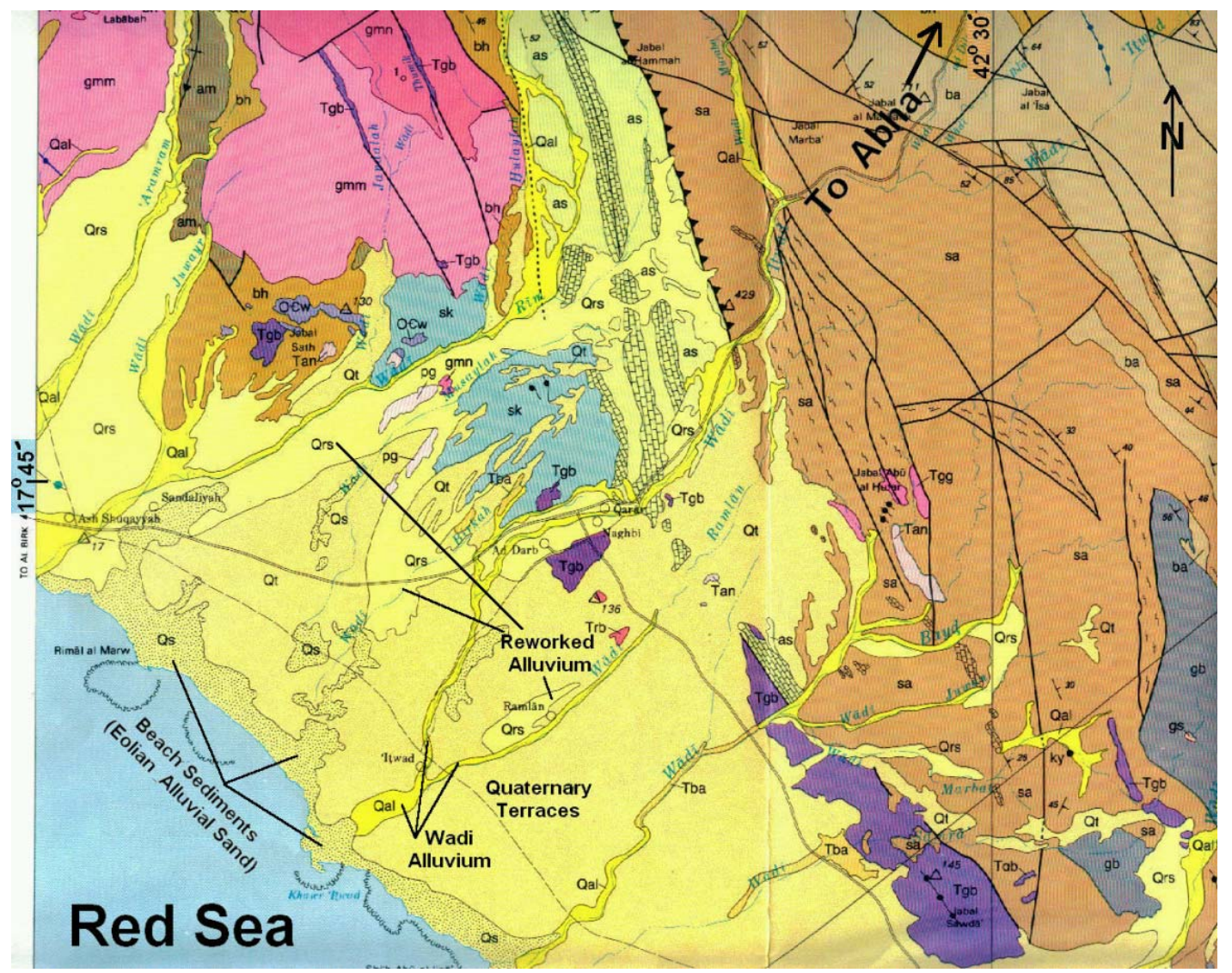

Figure 1. Different types of Quaternary deposits to the southwest of Abha area and possible Precambrian skarn outcrops, sky blue colour at center of the map (Fairer, 1985). 
The schists associating the marbles are mostly chloritic and graphitic with occasional occurrence of biotite and garnet indicating regional metamorphism in greenschist to lower amphibolite facies conditions. The schist itself shows remarkable mineral lineation and grain size variation turning the rock to phyllite in parts. The schists and phyllites are dissected by barren quartz veins and andesite dykes where the latter display distinct spheroidal weathering. In some instances, the marbles are invaded by conformable basaltic to andesitic sill. In many sites, the volume of marble seems much greater than that of the metasediment intercalations.

At some other sites, the marble is intercalated with mafic schists, mostly actinolite schist and in parts the marble becomes black and highly silicified. The contact between mafic schists and marble can be easily distinguished in the field where the contact is sometimes interrupted with mafic dykes. In other cases, the contact between mafic schists and marble facilitates the invasion of mafic sills in between. Deformation in marble is intense near major faults where shows fine grain size and becomes sliced and/or crenulated.

Some pinkish varieties of marbles were also identified at Ad Darb area where the pinkish variety is more deformed than the whitish and yellowish varieties. The pinkish variety sometimes associates purple schists and kinked graphite phyllite. From the stratigraphic point of view, these metasediments belong to the Bahah group which is underlain by dark agglomerates of the Jeddah group with coarse volcanic clasts. These are similar to metacarbonate of similar setting elsewhere in the world, e.g. [8].

The pelitic schists associating marble become mafic in some other sites and to amphibolite as well where the contact between marble and the mafic lithologies can be easily defined due to distinct colour variation. Stratigraphycally, both the schists and marble belongs to the Bahah group along major fault contacts with the underlying dark mafic agglomerates of the Jeddah group.

\subsection{Al Madhiq Calc-Silicate Rocks}

Ahmed [5,6] presented the first description of calc-silicate rocks at Al Madhiq area in Asir terrain (Figure 2) south to Abha and Khamis Mushayt cities, particularly about $20 \mathrm{~km}$ to the south of the latter city. Ahmed (op cit.) identified these calc-silicate rocks (rich in garnet) as "exoskarn" confined to amphibolites that were formed near upper margin of intrusive granitoids.

The area of Al Madhiq is occupied by a series of Precambrian rocks that are capped by Cambro-Ordovician sandstone of the Wajid Formation. The Precambrian basement rocks consist mainly of two groups, the first is a metamorphosed one (high-grade gneisses and schists) as a part of thick volcano-sedimentary succession, and second intrusive rocks that are dominated by granitoids. The granitoids comprise different types of gneissose granite and granodiorite, in a ddition to frequent pegmatites (up to $2.5 \mathrm{~m}$ thick) and aplite dykes. The gneisses themselves are represented mainly by hornblende gneiss that grades to amphibolites in part.

In the sense of skarn definition and mineralogy [9-12], Al Madhiq garnetiferous samples are not proper skarn but garnet is common like several calc-silicate minerals within metasedimentary terrains $[13,14]$.

Garnet at Al Madhiq occurrence often occurs in the form of bands conformable with rock foliation (gneissosity and schistosity). It occurs in bands of variable thickness in the range of $5-90 \mathrm{~cm}$ and associates dense quartz and epidote peripheral zones. The quartz-garnet bands are sometimes dislocated along normal faults defined by narrow aplite dykes.

Some specimen display clear rimming of garnet by epidote, which was supported microscopically as will be given in some back-scattered electron images (BSE). The paragenesis quartz-garnet-epidote is developed due to percolation of some Al-rich solutions along the rock foliation of hornblende gneiss, i.e. metasomatic garnet.

Careful field investigation collaborated with petrographic and SEM studies, suggest the occurrence of another garnetiferous paragenesis associating quartz, mica and feldspar in pegmatites, aplites and quartz veins, i.e. exclusively igneous garnet.

\section{XRD Runs of Al Madhiq Samples}

Some representative samples were selected for XRD runs of some samples from Al Madhiq area in order to define accurately the mineral paragenesis in the calc-silicates and igneous dykes (pegmatite \& aplite).

Two samples of garnetiferous calc-silicates were analyzed using the XRD technique after mineral purification in order to minimize the effect of co-existing minerals. It was obtained that the garnet is grossular (Figure 3) and this will be supported by the mineral chemistry in the next section.

On the other hand, igneous garnet in both pegmatite and aplite was hardly detected because of its low modal abundance $(\sim 5 \%)$. The resulted patterns were for major silicate minerals such as feldspars (microcline $\&$ albite) and quartz. It was possible to identify igneous garnets in these igneous dykes in samples investigated using the SEM technique. High magnification enables us to identify such igneous garnet and do spot chemical analysis for it. 


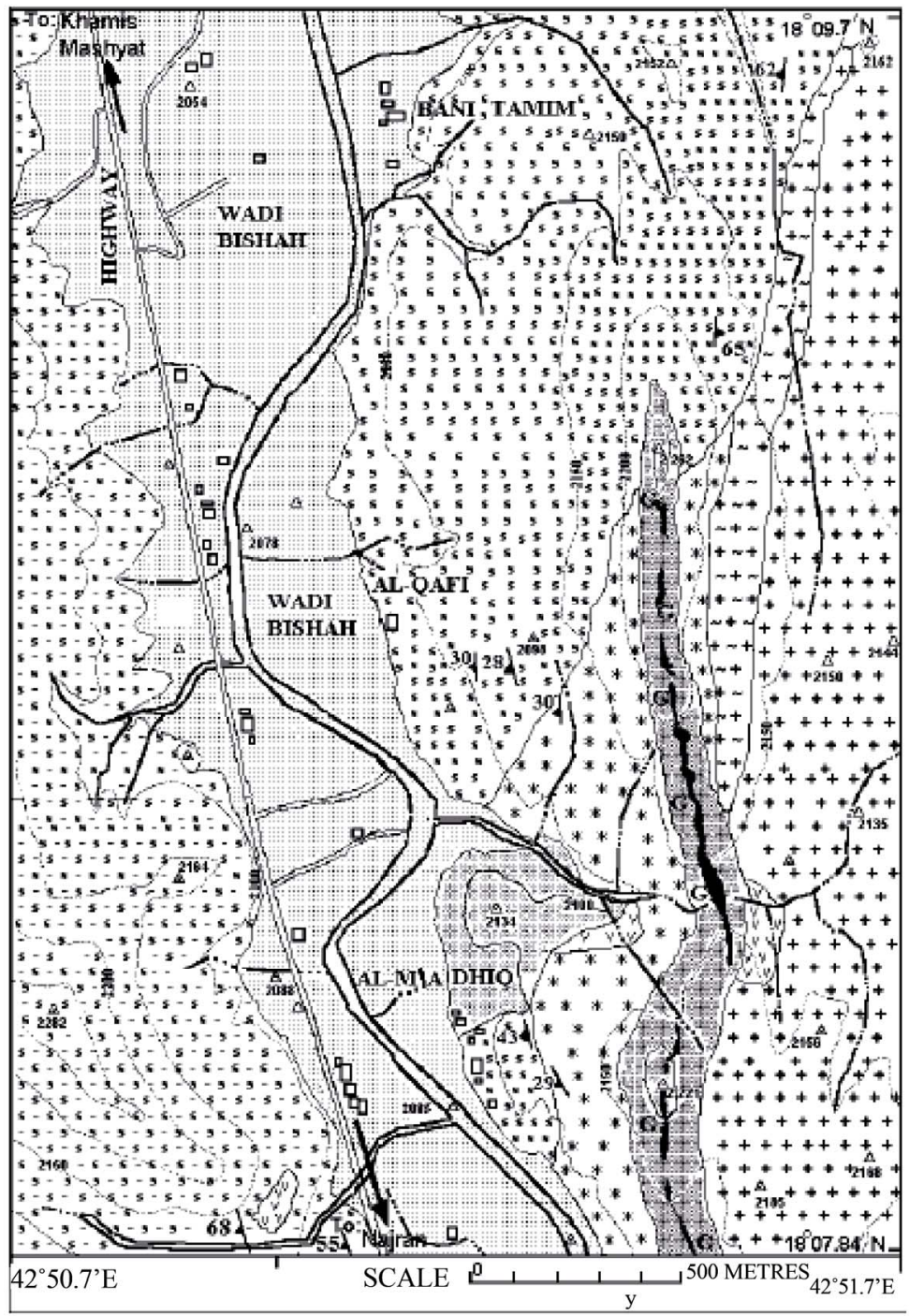

\begin{tabular}{|c|c|}
\hline his & Road \\
\hline समी & $\begin{array}{l}\text { Peak/Spot } \\
\text { Altitude }\end{array}$ \\
\hline & Ganyon \\
\hline$\square$ & Building \\
\hline 5 & Contour \\
\hline & Alluvium \\
\hline
\end{tabular}

\begin{tabular}{|c|c|}
\hline $68 d$ & Foliation \\
\hline vevyy & $\begin{array}{l}\text { Diorite } \\
\text { granodliorite }\end{array}$ \\
\hline & Garnet occurrence \\
\hline $\begin{array}{l}++*++* \\
+++++\end{array}$ & Granite \\
\hline $\begin{array}{l}+\cdots+\cdots+m \\
++\cdots+\cdots+\end{array}$ & Granite gneiss \\
\hline =inisin & Quartzite \\
\hline
\end{tabular}

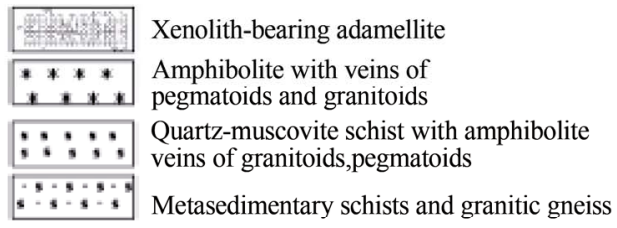

Figure 2. Detailed geological map of Al-Madhiq area at Asir terrain (Ahmed, 2002).

\section{Mineral Chemistry of Al Madhiq Garnetiferous Calc-Silicate Rocks}

The present section focuses on the chemical composition of mineral paragenesis of the studied calc-silicate rocks that are characterized by common occurrence of garnet, i.e. garnetiferous. On field, microscopic and mineral chemistry bases, it was possible to distinguish between two different types of garnet, 1) Metasomatic garnet (mainly grossular) in calc-silicate rocks, and 2) Igneous garnet (almandine-spessartine) dispersed in pegmatite and aplite dykes. Identification of different garnet species was possible based on XRD runs and optical discrimination following the mineralogicalchemical schemes of $[15,16]$. 

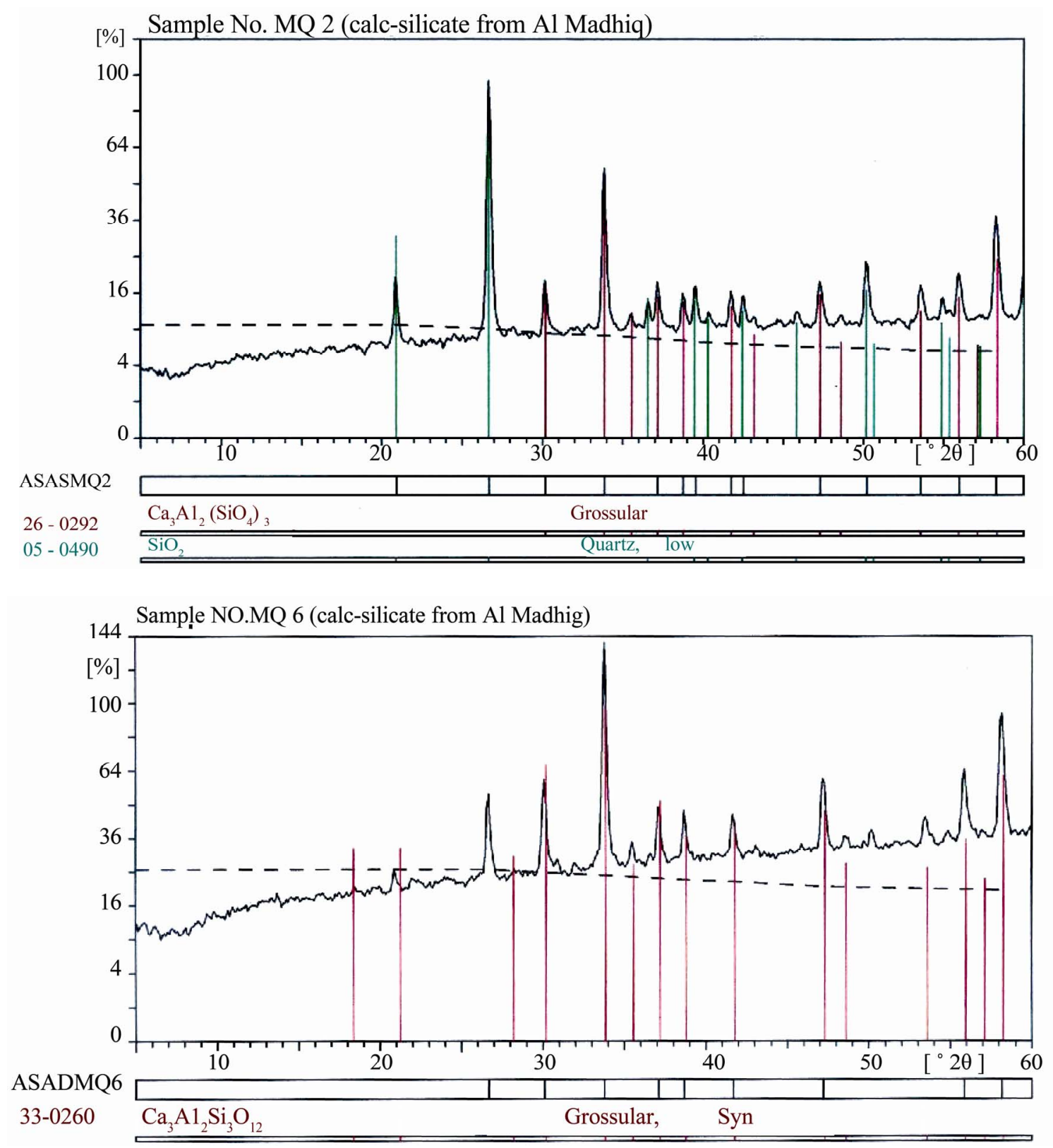

Figure 3. XRD patterns of garnetiferous calc-silicate samples from Al Madhiq area.

\subsection{Metasomatic Garnet and Epidote}

The metasomatic garnet is usually abundant (up to 70 modal \%), massive and occurs in the form of thick agglomerated garnet crystals in the form of bands. Such garnet bands can be traced megascopically and microscopically as meso- and micro-bands, respectively. Several garnetiferous calc-silicate samples were analyzed using the SEM-EDX technique in order to have a broad idea about the chemistry of existing garnet and other minerals in the paragenesis.

Spot chemical analyses given in Table 1, supported by
SEM back-scattered electron imaging (BSE), prove that the garnet in Al Madhiq calc-silicate rocks is either zoned or unzoned. Zoned crystals are much less common that the unzoned ones. The unzoned garnet is commonly coarse, locally sub-idioblastic and appears interstitial to other silicate phases (Figure 4). The last figure shows also abundant coarse quartz inclusions in this unzoned garnet of grossular composition. Considerable amounts of $\mathrm{Mg}$ and $\mathrm{Na}$ in parts of unzoned grossular are attributed to the presence of fine amphibole and albite inclusions with preferential concentration at the peripheral zone. Distribution of both $\mathrm{Ca}$ and $\mathrm{Fe}$ along rim-core-rim profile in 

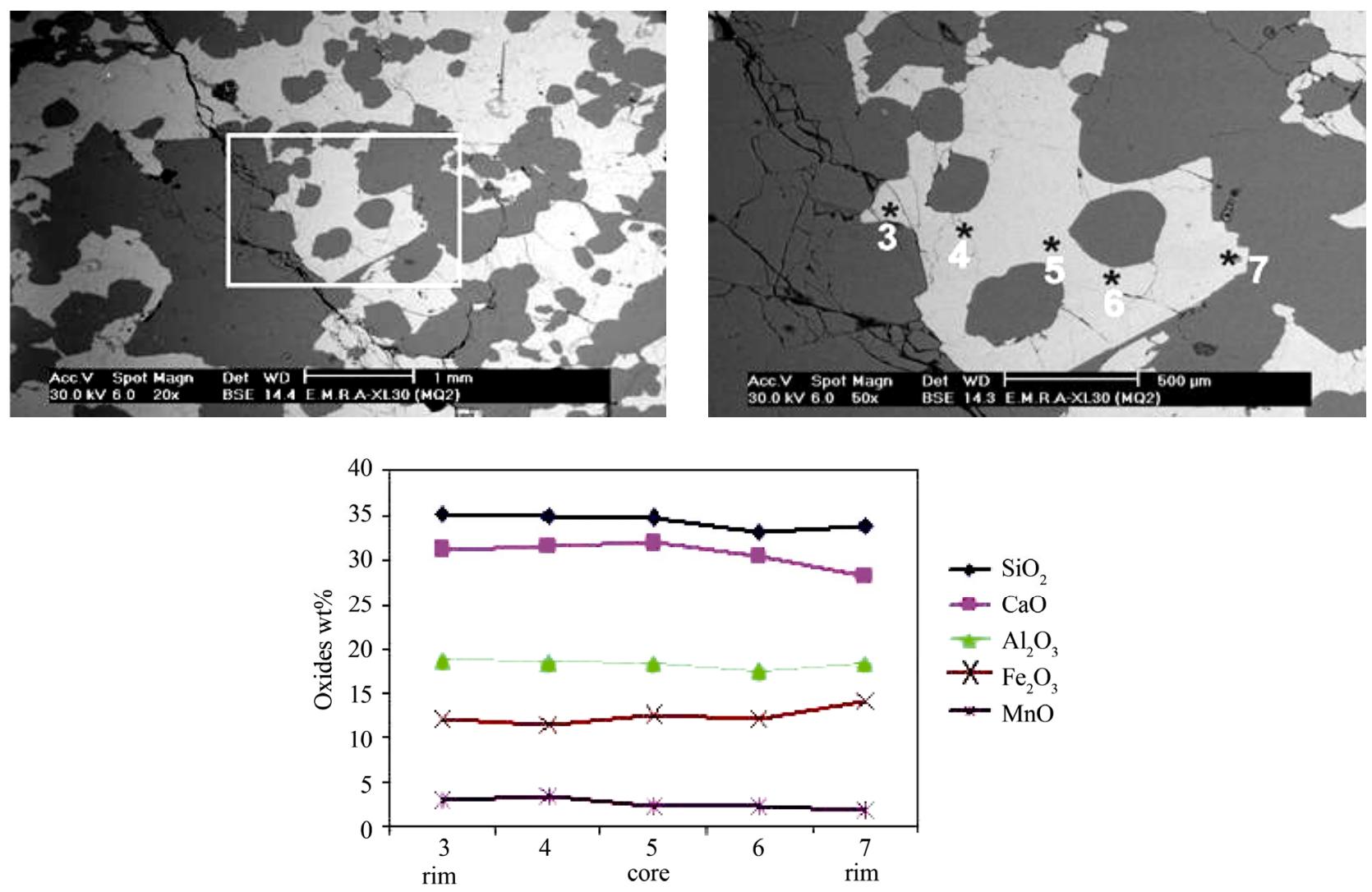

Figure 4. Very slight zoning in nearly unzoned grossular with coarse quartz inclusions.

Table 1. Spot microanalyses of metasomatic garnet profiles from Al Madhiq calc-silicates.

\begin{tabular}{|c|c|c|c|c|c|c|c|c|c|c|}
\hline \multirow{2}{*}{$\begin{array}{l}\text { Sample No. } \\
\text { Analysis No. }\end{array}$} & \multicolumn{5}{|c|}{ MQ 2} & \multicolumn{5}{|c|}{ MQ 2} \\
\hline & 3 & 4 & 5 & 6 & 7 & 8 & 9 & 10 & 11 & 12 \\
\hline Notes & $\mathrm{R}$ & IC & $\mathrm{C}$ & IC & $\mathrm{R}$ & $\mathrm{R}$ & IC & $\mathrm{C}$ & IC & $\mathrm{R}$ \\
\hline $\mathrm{SiO}_{2}$ & 35.03 & 34.91 & 34.71 & 33.09 & 33.82 & 34.93 & 35.91 & 35.01 & 35.90 & 34.43 \\
\hline $\mathrm{Al}_{2} \mathrm{O}_{3}$ & 18.77 & 18.58 & 18.35 & 17.48 & 18.32 & 18.30 & 20.57 & 19.60 & 21.66 & 19.13 \\
\hline $\mathrm{CaO}$ & 31.15 & 31.54 & 31.97 & 30.31 & 28.06 & 31.62 & 34.94 & 35.29 & 35.47 & 30.33 \\
\hline $\mathrm{Fe}_{2} \mathrm{O}_{3}$ & 11.99 & 11.51 & 12.67 & 12.02 & 14.23 & 12.17 & 6.04 & 6.82 & 5.31 & 12.99 \\
\hline $\mathrm{MgO}$ & - & - & - & - & 3.69 & - & - & - & - & - \\
\hline $\mathrm{MnO}$ & 3.05 & 3.46 & 2.30 & 2.22 & 1.89 & 2.99 & 2.54 & 2.55 & 1.67 & 3.11 \\
\hline $\mathrm{Na}_{2} \mathrm{O}$ & - & - & - & 4.88 & - & - & - & 0.74 & - & - \\
\hline Total & & & & Hypc & cally eq & to $100 \mathrm{w}$ & or all & & & \\
\hline
\end{tabular}

- Not detected

unzoned grossular is almost homogeneous where $\mathrm{CaO}$ ranges from $28.06 \mathrm{wt} \%$ to $31.97 \mathrm{wt} \%$ while $\mathrm{Fe}_{2} \mathrm{O}_{3}$ ranges from $11.51 \mathrm{wt} \%$ to $14.23 \mathrm{wt} \%$ (Table 1). These $\mathrm{Ca}$ and Fe contents may suggest that some rims of grossular would bear little andradite component in solid solution if it is compared with the core.

There are few zoned garnet crystals that can be ob- served both optically (Figure 5) and chemically (Table 1), where there core is represented by andradite while the rim is grossular. The andradite core is characterized by remarkable Fe-depletion where $\mathrm{Fe}_{2} \mathrm{O}_{3}$ lies in the range of $5.31 \mathrm{wt} \%-6.82 \mathrm{wt} \%$ whereas the amount is almost doubled at the rim (12.17 wt $\%$ - $12.99 \mathrm{wt} \%)$. The variation from andradite at core to grossular at rim is controlled by 
remarkable ionic substitution of $\mathrm{Fe}^{2+}$ for $\mathrm{Ca}^{2+}$ at the rim. The given spot analyses of metasomatic garnets (Table 1) either the zoned or unzoned show constant and similar ranges of $\mathrm{MnO}(1.67 \mathrm{wt} \%$ - $3.11 \mathrm{wt} \%$ and $1.89 \mathrm{wt} \%$ $3.46 \mathrm{wt} \%$, respectively). This indicates no possible ionic substitution of Mn by other divalent cations regardless the metasomatic garnet is zoned or not, i.e. constant spessartine component in soild solution from core to rim. Ahmed and Hariri [7] oppose such conclusion as they conclded that both spessartine and almandine in solid solution of Al Madahiq garnet from the same calc-silicate assemblage increase from core to rim. The present garnet analyses show agreement with Ahmed and Hariri [7] that grossular component decreases towards rim because this is applicable only to garnet crystals with distinct optical and chemical zoning.

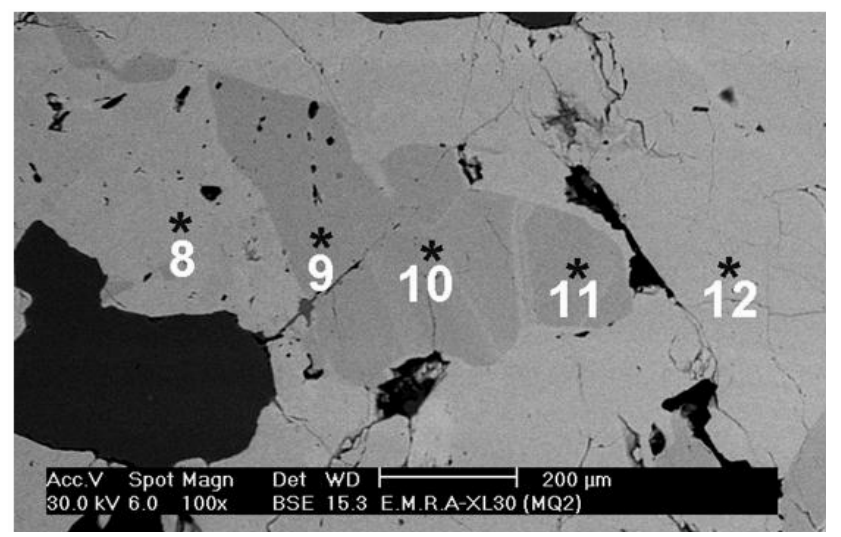

Spot analyses of independent garnet crystals from Al Madhiq calc-silicates (Table 2) indicate that they all for grossular from three selected samples, namely MQ 4, MQ $6 \&$ MQ 7. BSE images suggest that most of these crystals are unzoned and usually traversed and rimmed by epidote as a metasomatic mineral too that can be attributed to abrubt increase in alumina due to injection of felsic bodies, mostly alkali granitoids and related pegmatites and dykes. This hypothesis is supported by the appearance of few sporadic igneous garnet crystals (almandine, analysis\# 25, sample\# MQ 4) co-existing with metasomatic grossular (Table 2). An aluminous alkali-rich igneous fluid that injected the garnetiferous calc-silicates is also responsible for $2.00 \mathrm{wt} \% \mathrm{~K}_{2} \mathrm{O}$ in this occasional igneous almandine in the calc-silicates (Table 2).

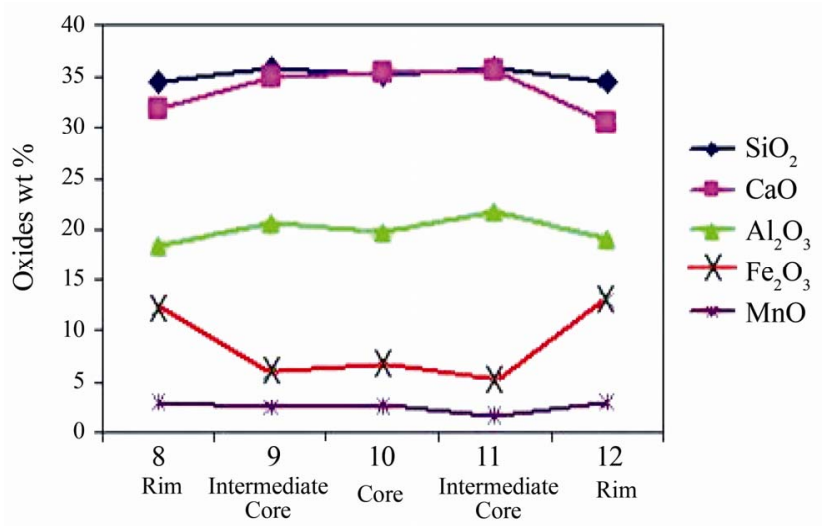

Figure 5. BSE image and chemical rim-core-rim profile of zoned grossular garnet crystal with andradite core.

Table 2. Microanalyses of independent metasomatic garnet crystals from Al Madhiq calc-silicates.

\begin{tabular}{|c|c|c|c|c|c|c|c|c|c|c|}
\hline \multirow{2}{*}{$\begin{array}{l}\text { Sample No. } \\
\text { Analysis No. }\end{array}$} & \multicolumn{5}{|c|}{ MQ 4} & \multicolumn{3}{|c|}{ MQ 6} & \multicolumn{2}{|c|}{ MQ 7} \\
\hline & 19 & 21 & 22 & 23 & 25 & 37 & 40 & 41 & 44 & 45 \\
\hline Notes* & Light grey & Light grey & Light grey & Light grey & Light grey & Light grey & $\begin{array}{l}\text { Light to } \\
\text { dark grey }\end{array}$ & Light grey & $\begin{array}{l}\text { Light to } \\
\text { dark grey }\end{array}$ & Light grey \\
\hline $\mathrm{Al}_{2} \mathrm{O}_{3}$ & 9.28 & 10.33 & 8.26 & 9.77 & 12.26 & 16.51 & 16.98 & 16.30 & 17.09 & 18.08 \\
\hline $\mathrm{CaO}$ & 28.73 & 30.67 & 26.79 & 26.68 & 11.60 & 34.73 & 34.30 & 33.85 & 30.60 & 30.29 \\
\hline $\mathrm{Fe}_{2} \mathrm{O}_{3}$ & 24.48 & 21.12 & 27.02 & 22.70 & 30.92 & 13.67 & 12.46 & 12.30 & 14.65 & 14.50 \\
\hline $\mathrm{MgO}$ & - & - & - & 4.57 & 4.31 & - & - & - & 1.42 & - \\
\hline $\mathrm{TiO}_{2}$ & 0.87 & - & - & 0.97 & - & - & - & - & - & - \\
\hline $\mathrm{K}_{2} \mathrm{O}$ & - & & & - & 2.00 & - & - & - & - & - \\
\hline Total & & & & Hypothe & etically equa & ls to $100 \mathrm{wt}^{0}$ & $\%$ for all & & & \\
\hline
\end{tabular}

- Not detected. * Tone of grey shades as observed on the back-scattered electron (BSE) images. 
BSE images that are shown in Figure 6 witness invasion of metasomatic grossular garnet with metasomatic epidote. Epidotization of grossular is either regular along sub-parallel cubic cleavage or irregular depending on the intense of replacement (Figure 6(a)). Someimes, epidote appears invading and rimming grossular (Figure 6(b)).
In some few instances, epidote severely replacing grossular (Figure 6(c)) represents immature epidote composition with garnet fingerprints (analysis\# 47, Table 3). Such analysis shows considerable alkali content (6.40 wt\% $\mathrm{Na}_{2} \mathrm{O}$ ) that again supports metasomatic origin of epidote contemporaneous with the injection of felsic bodies.

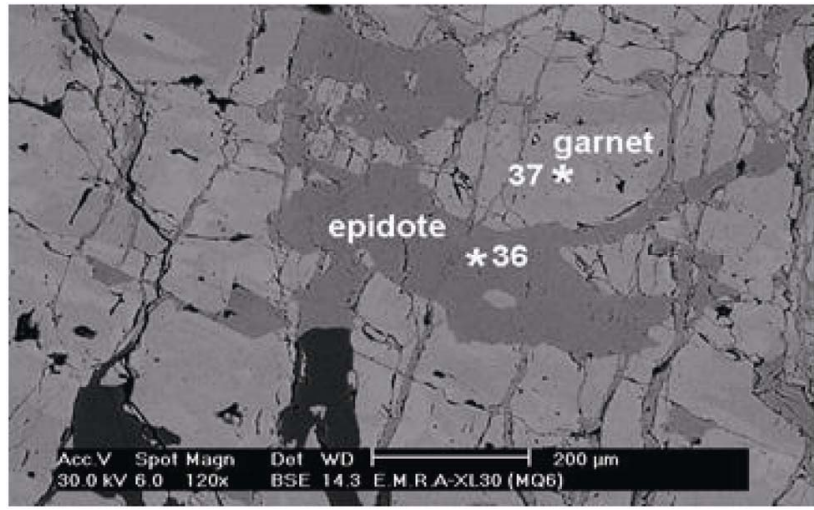

(a)

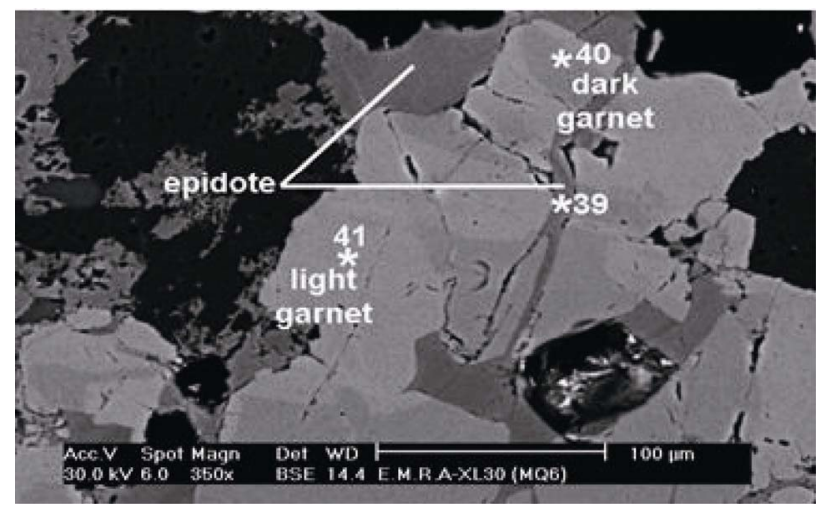

(b)

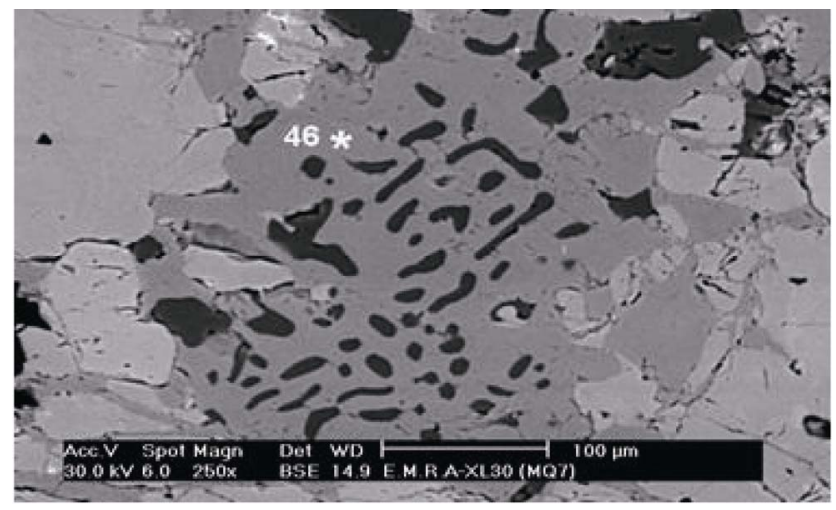

(c)

Figure 6. BSE images of analyzed epidote showing its textural relationship with grossular. (a) Epidote invading grossular garnet. (b) Epidote rimming and invading garnet. (c) Epidote (with verimiclar quartz inclusions, dark grey) replacing grossular (light grey).

Table 3. Spot analyses of epidote associating garnet in Al Madhiq calc-silicates.

\begin{tabular}{|c|c|c|c|c|c|c|}
\hline \multirow{2}{*}{$\begin{array}{l}\text { Sample No. } \\
\text { Analysis No. }\end{array}$} & \multicolumn{3}{|c|}{ MQ 4} & \multicolumn{2}{|c|}{ MQ 6} & \multirow{2}{*}{$\begin{array}{r}\text { MQ } 7 \\
47^{*}\end{array}$} \\
\hline & 18 & 20 & 24 & 36 & 39 & \\
\hline $\mathrm{SiO}_{2}$ & 36.64 & 35.17 & 35.49 & 35.52 & 37.00 & 33.32 \\
\hline $\mathrm{Al}_{2} \mathrm{O}_{3}$ & 22.74 & 21.48 & 21.20 & 24.75 & 24.41 & 22.94 \\
\hline $\mathrm{CaO}$ & 23.63 & 25.09 & 24.36 & 26.95 & 26.24 & 15.05 \\
\hline $\mathrm{Fe}_{2} \mathrm{O}_{3}$ & 16.98 & 18.26 & 17.33 & 12.78 & 12.35 & 11.91 \\
\hline $\mathrm{MgO}$ & - & - & 1.62 & - & - & - \\
\hline Total & \multicolumn{6}{|c|}{ Hypothetically equals to $100 \mathrm{wt} \%$ for all } \\
\hline
\end{tabular}




\subsection{Igneous Garnet}

Modal percentage of igneous garnet in pegmatites and aplites is remarkably low (up to $5 \%$ only). It occurs as dispersed crystals in these felsic rocks. Sometimes, nonequant garnet can be observed adjacent to mica flakes (Figure 7(a)) where it is cracked and xenomorphic. Cracking in other garnet crystals is rarely found (Figure 7(b)). Equant sub-idiomorphic garnet are common occurring interstitially to quartz and sodic feldspar (Figures 7(c) and (d)). Figure c documents the presence of fine zircon inclusions in both garnet and other silicates.

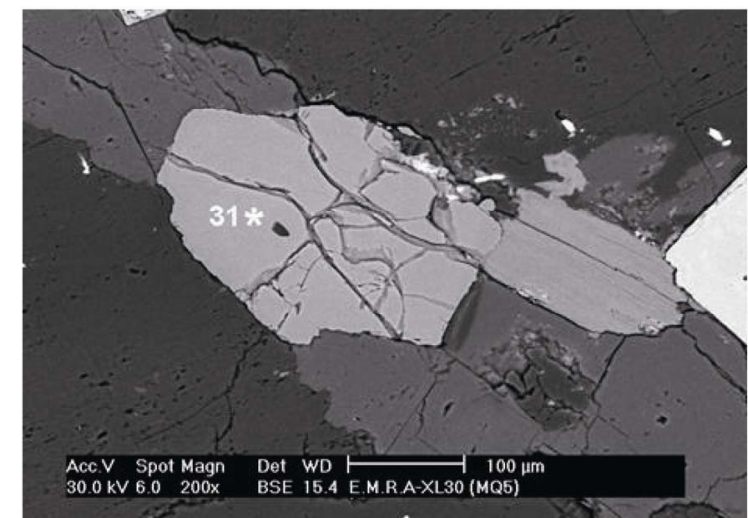

(a)

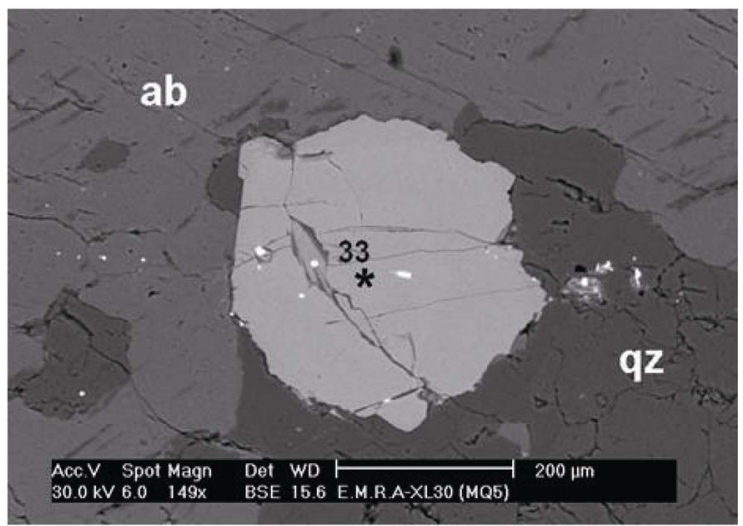

(c)
Geochemically, the igneous garnet is transitional in composition between almandine and spessartine (Table 4) and hence it can be safely considered as Fe-Mn garnet that characterizes aluminous and peraluminous granitoids. Garnet crystal with maximum spessartine component has the highest $\mathrm{MnO}$ and $\mathrm{Fe}_{2} \mathrm{O}_{3}$ contents (analysis\# 48 with $25.59 \mathrm{wt} \%$ and $16.79 \mathrm{wt} \%$ respectively) indicating ionic substitution between $\mathrm{Mn}^{2+}$ and $\mathrm{Fe}^{2+}$ (Table 4). Also, some almandine-spessartine crystals witness limited cationic exchange between $\mathrm{Mn}^{2+}$ and $\mathrm{Ca}^{2+}$ where $\mathrm{CaO}$ attains the value of $7.32 \mathrm{wt} \%$ (analysis\# 32, Table 4).

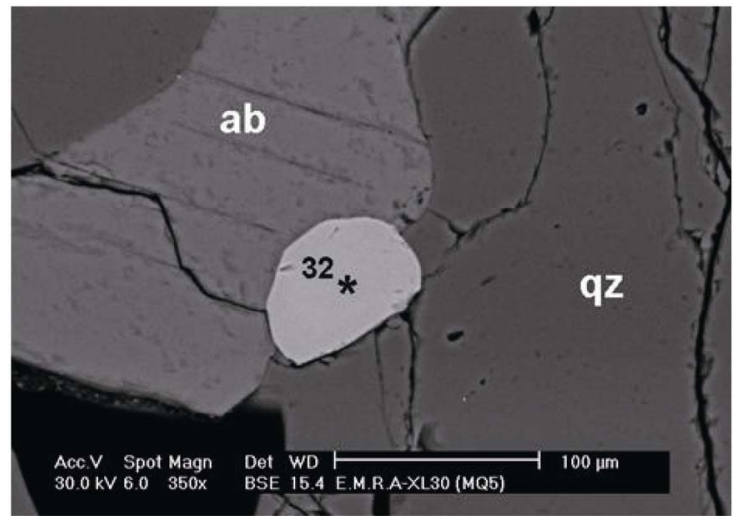

(b)

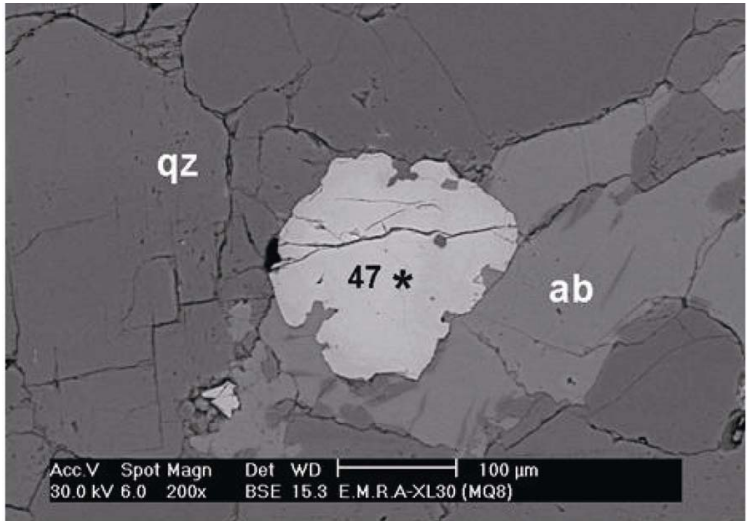

(d)

Figure 7. BSE of Fe-Mn garnet in igneous bodies. (a) Cracked garnet associating mica in pegmatite. (b) Uncracked garnet in between albite (ab) and quartz (qz) in pegmatite. (c) Cracked equant garnet in between albite (ab) and quartz (qz) in pegmatite. Notice fine zircon inclusions (bright spots). (d) Subhedral garnet in between albite (ab) and quartz (qz) in aplite.

Table 4. Microanalyses of igneous Fe-Mn garnet (fine, cracked \& uncracked).

\begin{tabular}{|c|c|c|c|c|c|}
\hline \multirow{2}{*}{$\begin{array}{l}\text { Sample No. } \\
\text { Analysis No. }\end{array}$} & \multicolumn{3}{|c|}{ MQ 5} & \multicolumn{2}{|c|}{ MQ 8} \\
\hline & 31 & 32 & 33 & 47 & 48 \\
\hline $\mathrm{SiO}_{2}$ & 32.43 & 33.63 & 33.15 & 34.39 & 32.43 \\
\hline $\mathrm{Al}_{2} \mathrm{O}_{3}$ & 19.00 & 19.57 & 20.97 & 20.01 & 20.29 \\
\hline $\mathrm{CaO}$ & 4.02 & 7.32 & 2.84 & 4.30 & 4.90 \\
\hline $\mathrm{Fe}_{2} \mathrm{O}_{3}$ & 26.14 & 24.61 & 19.62 & 19.42 & 16.79 \\
\hline $\mathrm{MnO}$ & 18.40 & 14.88 & 23.42 & 21.88 & 25.59 \\
\hline Total & \multicolumn{5}{|c|}{ Hypothetically equals to $100 \mathrm{wt} \%$ for all } \\
\hline
\end{tabular}




\subsection{Zircon}

Survey both igneous and calc-silicate samples using the scanning electron microscope (SEM) revealed the presence of abundant zircon in both types. Zircon in the calc-silicates is most probably of igneous protolith being connected to the metasomatized ortho-gneisses (mostly hornblende gneiss). It is euhedral and some of it occurs as hollowed crystals or cracked zoned ones.

Spot analyses of zircon from either pegmatites (sample\# 5) or clac-silicates (samples\# 2 \& 6) lack any radioactive elements such as $\mathrm{U}$ or $\mathrm{Th}$ and hence all the tabulated analyses of zircon is for non-mentamict variety (Table 5). Traces of $\mathrm{Ca}, \mathrm{Fe}$ and $\mathrm{Al}$ are attributed to fine silicate inclusions in relatively coarser zircon crystals. Zircon analysis\# 30 with 21.23 wt $\% \mathrm{Fe}_{2} \mathrm{O}_{3}$ (Table 5) owes such very high Fe-content to hematite impurities. Both igneous and metasomatic zircons are Hf-free.

\subsection{Feldspar and Amphibole}

The presented analyses of feldspars are from pegmatite whereas amphibole is from calc-silicate (Table 6). It is evident that the there are two varieties of feldspar in the pegmatite, one as microcline perthite and the other is homogeneous albite. The analyzed microcline spot in the perthite is exclusively potassic with neither traces of $\mathrm{Na}$ nor $\mathrm{Ca}$ (analysis\# 26, Table 6). Plagioclase is almost sodic with very little anorthite component in solid solution where $\mathrm{CaO}$ amounts 1.24 only. Mineral chemistry of the different varieties of feldspars in the pegmatites and aplites is supported by the microscopic investigation as well as the XRD runs.

The presented amphibole from the calc-silicate is hornblende, which occurs as relics in growing epidote cluster and the hornblende itself contains euhedral apatite. Analysis\# 42 of this apatite is not tabulated because it is solely formed of $\mathrm{Ca}$ and $\mathrm{P}$ oxides only.

Table 5. Spot analyses of zircon from Al Madhiq area.

\begin{tabular}{|c|c|c|c|c|c|}
\hline Sample No.* & MQ 2 & MQ 5 & & MQ 6 & \\
\hline Analysis No. & 2 & 30 & 34 & 35 & 38 \\
\hline $\mathrm{SiO}_{2}$ & 36.43 & 29.55 & 35.35 & 31.30 & 36.73 \\
\hline $\mathrm{ZrO}_{2}$ & 63.57 & 49.22 & 53.50 & 67.85 & 60.06 \\
\hline $\mathrm{Fe}_{2} \mathrm{O}_{3}$ & - & 21.23 & 7.32 & - & - \\
\hline $\mathrm{CaO}$ & - & - & 3.83 & 0.85 & - \\
\hline $\mathrm{Al}_{2} \mathrm{O}_{3}$ & - & - & - & - & 3.22 \\
\hline Total & \multicolumn{5}{|c|}{ Hypothetically equals to $100 \mathrm{wt} \%$ for all } \\
\hline
\end{tabular}

- Not detected. * MQ 2 \& MQ 6 are calc-silicates, whereas MQ 5 is pegmatite.

Table 6. Spot analyses of feldspars* and amphibole** from al madhiq area.

\begin{tabular}{|c|c|c|c|}
\hline Mineral & $\begin{array}{l}\text { K-feldspar in perthite } \\
\text { (microcline) }\end{array}$ & Na-plagioclase (albite) & Amphibole \\
\hline Sample No. & MQ 5 & MQ 5 & MQ 7 \\
\hline Analysis No. & 26 & 29 & 43 \\
\hline $\mathrm{SiO}_{2}$ & 64.22 & 50.93 & 40.85 \\
\hline $\mathrm{Al}_{2} \mathrm{O}_{3}$ & 20.18 & 22.53 & - \\
\hline $\mathrm{TiO}_{2}$ & - & - & - \\
\hline $\mathrm{CaO}$ & - & 1.24 & 20.27 \\
\hline $\mathrm{Fe}_{2} \mathrm{O}_{3}$ & - & - & 18.45 \\
\hline $\mathrm{MgO}$ & - & - & - \\
\hline $\mathrm{MnO}$ & - & - & - \\
\hline $\mathrm{Na}_{2} \mathrm{O}$ & - & 25.30 & 15.31 \\
\hline $\mathrm{K}_{2} \mathrm{O}$ & 15.59 & - & - \\
\hline Total & \multicolumn{3}{|c|}{ Hypothetically equals to $100 \mathrm{wt} \%$ for all } \\
\hline
\end{tabular}

- Not detected. * from pegmatite (igneous rock member). ** from calc-silicate (metasomatic rock member) 


\subsection{Sulphides}

Ore microscopic investigation collaborated with the BSE images revealed that sulphides are absent in the studied pegmatites and aplites but some are encountered in the calc-silicates, e.g. samples\# 2 \& 4. Sulphides in the calcsilicates are dominated by pyrite that displays distinct size and abundance variations.

Also, mode of occurrence of pyrite varies as it in cases occurs as fresh pentagonal pyritohedron as inclusions in grossular. This is a probable clue for reducing conditions for development of host metasomatic grossular garnet. This is also supported by the common existence of pyrite with a metasomatic mineral assemblage rich in grossular and epidote. Coarse pyrite crystals are often oxidized to colloform bands of goethite and semi-mineraloid aggregate in the form of "limonite". Chalcopyrite, when present, occurs as fine inclusion in much coarser pyrite.

Chemical analyses of pyrite and chalcopyrite are presented in Table 7 that shows few traces of $\mathrm{Cu}$ of 2.51 $\mathrm{wt} \%$ in the structure of pyrite hosting chalcopyrite.

\section{Conclusions}

1) Current field observations by the present author proved that there are no skarns at Ad darb area, and the whole mass of metacarbonates is actually marble deposits intercalated with schists and phyllites of different compositions. The marble and associated metasediments lie to the west of striking ridges of marbles that are aligned nearly in the NNW-SSE direction.

2) Garnet at Al Madhiq occurrence often occurs in the form of bands conformable with rock foliation (gneissosity and schistosity). It occurs in bands of variable thickness in the range of $5-90 \mathrm{~cm}$ and associates dense quartz and epidote peripheral zones. The quartz- garnet bands are sometimes dislocated along normal faults defined by narrow aplite dykes.

Table 7. Spot analyses of sulphides from Al Madhiq calcsilicates.

\begin{tabular}{cccc}
\hline Mineral & \multicolumn{2}{c}{ Pyrite } & Chalcopyrite \\
\hline Sample No. & MQ 2 & MQ 4 & MQ 4 \\
\hline Analysis No. & 1 & 17 & 16 \\
Notes & Fresh & Relics in collformed & Relics in collformed \\
$\mathrm{S}$ & 39.38 & goethite & goethite \\
$\mathrm{Fe}$ & 60.62 & 25.91 & 19.89 \\
$\mathrm{Cu}$ & - & 2.51 & 16.68 \\
$\mathrm{Si}$ & - & - & 59.07 \\
Total & & Hypothetically equals to $100 \mathrm{wt} \%$ for all
\end{tabular}

- Not detected.
3) The present project argues that Al Madhiq garnet deposits can not be classified as garnetiferous skarn because of the followings: a] absence of any carbonate minerals and marbles in the paragenesis, b] confinement of the garnet bands to main structural trends and rock schistosity and gneissosity, c] common occurrence of silica and even quartzite bands associateing garnet bands, and finally d] zoned garnet crystals at the garnet-country rocks contact are uncommon indicating weak fluid circulation in contrast to thermal aureoles icharacterizing skarn deposits.

4) It is suggested that the paragenesis quartz-garnetepidote is developed due to percolation of some Al- rich solutions along the rock foliation of hornblende gneiss, i.e. metasomatic garnet. Careful field investigation collaborated with petrographic and SEM studies, suggest the occurrence of another garnetiferous paragenesis associating quartz, mica and feldspar in pegmatites, aplites and quartz veins, i.e. exclusively igneous garnet.

5) Metasomatic garnet in clac-silicates of Al Madhiq is of grossular composition. It is commonly unzoned but some distinctly to slightly zoned crystals are observed where the core is andradite-rich and the rim is grossular.

6) Metasomatic events responsible for growth of garnet in the calc-silicates led also to formation of epidote post-dating grossular. Handspecimen, microscopic investigation and BSE images prove that this epidote postdates and replaces grossular, and even rims it in some instances.

7) Igneous garnet at Al Madhiq is observed in pegmatites and aplites connected to alkali granitoids. In this case, the garnet is intermediate in composition between almandine and spessartine. The present study is the first record of igneous garnet in these felsic dykes because previous studies in the same locality failed to record igneous garnet in the pegmatites cutting the granitoids, gneisses and amphibolites, e.g. [7].

8) Zircon in igneous dykes (pegmatites \& aplites) and metasomatic calc-silicates is non-metamict and of ortho-origin in both cases.

\section{References}

[1] D. Laurent, "Ornamental Stones," In: P. Collenette and D. J. Grainger, Eds., Mineral Resources of Saudi Arabia, not including Oil, Natural Gas, and Sulfur, Ministry of Petroleum and Mineral Resources, Directorate General of Mineral Resources, Jeddah, 1984, pp. 200-206.

[2] B. Lemiere and G. Baudet, "Wollastonite," In: B. Collenette and D. J. Grainger, Eds., Mineral resources of Saudi Arabi, Ministry of Petroleum and Mineral Resources, Jeddah, 1994, pp. 280-283.

[3] B. Lemiere, N. Damanhori and G. Baudet, "A MarbleHosted Wollastonite Deposit at Bi'r Ash Shumt, King- 
dom of Saudi Arabia," Earth Sciences Journal, Vol. 3, No. 1, 1990, pp. 129-144.

[4] G. M. Fairer, "Geology of the Wadi Baysh Quadrangle, Sheet 17F, Kingdom of Saudi Arabia," Ministry of Petroleum and Mineral Resources, Deputy Ministry for Mineral Resources, Jiddah, 1985.

[5] Z. Ahmed, "First Report on Metasomatic Garnets from Al Madhiq Area, SW Saudi Arabia," Proceedings of the First Saudi Science Conference, Vol. 3, 2001, pp. 177184.

[6] Z. Ahmed, "Composition of Skarn Grossular from AlMadhiq Area, SW Saudi Arabia," The Arabian Journal for Science and Engineering, Vol. 27, No. 1A, 2002, pp. 3-16.

[7] Z. Ahmed and M. M. Hariri, "Formation and Mineral Chemistry of a Calcite Skarn from Al-Madhiq, SW Saudi Arabia," Chemie der Erde-Geochemistry, Vol. 66, No. 4, 2006, pp. 187-201. doi:10.1016/j.chemer.2004.10.001

[8] V. L. Sanchez-Vizciano and J. I. Soto, "Metamorphism of Calc-Silicate Rocks from the Alboran Basement," In: R. N. Riegel, Ed., Proceedings of the Ocean Drilling Program, Vol. 161, 1999, pp. 974-979.

[9] D. M. Burt, "Skarn dEPOSITS-HISTORICAL BIBLIOGRAPHY through 1970," Economic Geology, Vol. 77, No.
4, 1982, pp. 755-763. doi:10.2113/gsecongeo.77.4.755

[10] L. D. Meinert, "Skarns and Skarn Deposits," Geoscience Canada, Vol. 19, No. 4, 1992, pp. 145-162.

[11] L. D. Meinert, "A Review of Skarns That Contain Gold, In: D. R. Lentz, Eds., Mineralized Intrusion-Related Systems: Mineralogical Association of Canada Short Course Series, Vol. 26, 1998, pp. 359-414.

[12] I. Kuşcu, "Geochemistry and Mineralogy of the Skarns in the Çelebi District, Kirikkale, Turkey," Turkish Journal of Earth Sciences, Vol. 10, No. 3, 2001, pp. 121-132.

[13] K. Bucher and M. Frey, "Petrogenesis of Metamorphic Rocks" 7th Edition, Springer, Heidelberg, 2002, p. 341.

[14] T. A. Grammatikopoulos and A. H. Clark, "A ComparaTive Study of Wollastonite Skarn Genesis in the Central Metasedimentary Belt, Southeastern Ontario, Canada," Ore Geology Reviews, Vol. 29, No. 2, 2006, pp. 146-161. doi:10.1016/j.oregeorev.2005.11.007

[15] E. Passaglia and R. Rinaldi, "Katoite, a New Member of the $\mathrm{Ca}_{3} \mathrm{Al}_{2}\left(\mathrm{SiO}_{4}\right)_{3}-\mathrm{Ca}_{3} \mathrm{Al}_{2}(\mathrm{OH})_{12}$ Series and a New nomenclature for the Hydrogrossular Group of Minerals," Bulletin de Mineralogie, Vol. 107, 1984, pp. 605-618.

[16] G. R. Rossman, G. R. and R. D. Aines, "The Hydrous Com Ponents in Garnets: Grossular-Hydrogrossular," American Mineralogist, Vol. 76, 1991, pp. 1153-1164. 